\title{
Comparison of Antioxidant and Antimicrobial Activities of Supercritical Fluid Extracts and Marc Extracts from Cinnamomum verum
}

\author{
Sung Jin Park ${ }^{1+}$, Mi Hee Yü ${ }^{1+}$, Ji Eun Kim', Sam Pin Lee ${ }^{1,2}$ and In Seon Lee ${ }^{1} \star$ \\ ${ }^{1}$ The Center for Traditional Microorganism Resources, Keimyung University, Daegu 704-701, Korea \\ ${ }^{2}$ Department of Food Science and Technology, Keimyung University, Daegu 704-701, Korea
}

Received December 9, 2011 / Revised March 14, 2012 / Accepted March 14, 2012

\begin{abstract}
This study was performed to evaluate the antioxidant and antimicrobiological effects of supercritical fluid extracts (SFEs) and Marc methanol extracts (SFMs) from Cinnamomum verum Reducing effects on 1,1-diphenyl-2-picrylhydrazyl (DPPH) radical and ABTS radical scavenging were investigated. SFM exhibited higher antioxidant activities in DPPH and ABTS radical scavenging assay. Measurements of the antimicrobial activity were used for Gram-positive bacteria (four strains) and Gram-negative bacteria (four strains). The antimicrobial activities of the SFE and SFM against gram-positive and gram-negative bacteria revealed that SFE had a higher inhibition zone than SFM. Cinnamaldehyde, the active compound of $C$. verum, had a higher content in SFM $\left(35 \%\right.$ at 300 bar, $\left.30^{\circ} \mathrm{C}\right)$ than methanol extracts from $C$. verum $(0.5 \%)$. These results indicate that not only SFE oil, but also SFM, could be a good source for the food industry.
\end{abstract}

Key words : Supercritical fluid extracts, antimicrobial, antioxidative, cinnamon, cinnamaldehyde

\section{서 론}

최근 생활수준이 향상됨에 따라 천연식품에 대한 소비자들 의 선호 경향이 높아지고 식용 가능한 식물들에 대한 새로운 식품학적 가치가 인정되면서 천연물 유래의 활성물질 탐색에 연구가 집중되고 있으며, 이러한 천연 식물 자원을 대상으로 항균, 항산화, 항암을 비롯한 성인병 예방 및 면역증강 등에 대한 연구가 활발히 진행되고 있다 $[5,17,20,21]$. 산소는 호흡을 하는 생물인 인체 내에서 꼭 필요한 원소이지만 외부적인 자 극이나, 에너지 대사 과정 중에 발생하는 superoxide, nitric oxide, hydroxyl, peroxyl, alkoxyl, hydroperoxyl radical과 같 은 활성산소종(Reactive oxyzen species)은 미토콘드리아와 같 은 세포 내 기관의 정상적인 대사 및 세포질 내 일부 효소들에 의하여 자연적으로 생성되며, 세포 내에 적당량이 존재할 경 우 여러 가지 세포반응을 조절하는 인자가 된다. 하지만 과량 의 활성산소종은 DNA 분절과 단백질의 불활성화 및 세포 생 체막의 구성성분인 불포화 지방산을 공격하여 생체기능을 저 하시킴으로써 노화를 유발 할 뿐만 아니라 류마티스성 관절 염, 당뇨병, 심장병, 동맥경화, 암 등과 같은 여러 질환의 원인 으로 잘 알려져 있다[13,25]. 생체 내에는 활성산소로부터 세포 를 보호하기 위한 방어 시스템이 있지만[7], 현대인들은 환경 오염, 스트레스, 식습관으로 활성산소에 노출되어 있다. BHT (butylated hydroxytoluene), BHA (butylated hydrox-

\footnotetext{
${ }^{\dagger}$ These authors contributed equally to this work

${ }^{*}$ Corresponding author

Tel : +82-53-580-5538, Fax : +82-53-580-5538

E-mail : inseon@kmu.ac.kr
}

yanisole), PG (proply gallate), TBHQ (tertiary butyihydroquinone), ascorbic acid, tocopherol류, $\beta$-carotene 등은 활 성산소를 차단하는 항산화제로서 사용되고 있지만[1], 지질변 화 및 발암독성 때문에 사용이 제한되므로 천연식물 추출물이 생체 내 항산화 방어시스템을 증가시키거나 ROS를 소거시키 는 효과가 있다면 그 추출물은 다양한 질병을 예방하기 위한 기능성 소재로 사용 될 수 있을 것이다[11].

또한 전 세계적으로 합성 식품첨가물에 대한 안정성과 사용 규정들이 다시 검토되면서 식품의 위생관념이 철저해지고 있 는 추세이다. 그러나 지구 온난화 및 실내온도 상승 등 환경뿐 만 아니라 외식의 확대와 학교급식의 의무화 등과 같은 단체 급식의 확대로 식중독 발생이 지속적으로 증가 하고 있는 추 세이다[3]. 국내 식중독 발생 현황은 2008년 354건, 7,453명으 로 100 만명 당 153.8 명에 이른다[14]. 식중독의 원인체는 Escherichia coli, Salmonella sp, Staphylococcus aureus, Vibrio parahaemolyticcus 등이 주요 세균성 식중독의 원인체이며, 식중독 원인체가 불명확한 것을 제외한 전체 식중독의 $95 \%$ 가 식품위 해미생물에 의한 식중독이 차지하고 있다. 이러한 식중독 원 인 미생물이나 부패 미생물을 제어하여 식품을 안전하게 저장 하기 위한 수단으로 nitrite, sorbic acid, sodium metabisulfite, 염소제 등 다양한 합성 보존료가 장기간 사용되어왔다[2]. 하 지만 소비자들의 건강 지향적 욕구 증가와 안정성에 대한 의 식 고조로 천연항균물질에 대한 선호 인식이 높아지고 있다.

계피(Cinnamomum verum) 는 중국 남부 및 북 베트남에서 주로 많이 생산된다. 모양은 반관상, 반통상 또는 한쪽으로 말려 들어가 있는 관상의 껍질인데, 대부분 조각 형태로, 크기 는 다양하다. 바깥 면은 짙은 적갈색이고 내면은 평탄하나 역 
시 적갈색이고 파절이 용이하다. 특이한 향이 있고 맛은 처음 에 약간 달고 매우며 나중에는 점액성을 띄고 떫다. 성분은 cinnamic aldehyde가 주성분이며, 그 외에도 cinnamyl acetate, phenylpropylacetate, cinnamic acid, salicylaldehyde 등 이 있으며, diterpenoid류로는 cinnzeylanol이 존재한다. 그 외 에도 정유(essential oil)로서 camphene, cineole, eugenol 등이 있다. 계피는 다양한 효능과 향이 있어 한방 및 민간요법에서 널리 사용되어 왔으며, 차, 음료 또는 한약의 재료로 오랫동안 사용되고 있다. 알려진 약리작용으로는 혈압강화, 말초혈관 확장, 혈액순환이 있고, 한방에서는 감기, 진통에 사용되고 있 다[27,28,29].

이처럼 질병의 치료와 예방을 위해 천연물로부터 유용성 성분을 분리하는 많은 연구방법이 제시되어 왔다. 그러나 대 부분의 천연유효성분은 그 구조가 매우 복잡하고 정교할 뿐만 아니라 불안정하여 이들을 효율적으로 추출하는데 어려움이 있다. 현재 식물 내 유효성분을 추출하기 위한 방법으로는 특 정 용매에 대한 구성물의 용해도 차이를 이용하는 용매 추출 법이 널리 쓰이고 있지만, 이는 높은 온도를 장시간 사용해야 함으로써 발생하는 유용성분의 변성이나 파괴가 야기되고, 사 용된 용매의 일부가 유용성분에 잔존할 가능성이 있어 이용에 제한적이다[18]. 따라서 위의 단점을 보완하기 위한 추출법으 로써 초임계 유체를 이용한 초임계 추출법이 주목 받고 있다. 초임계 추출공법은 저온에서 조작할 수 있어 천연물과 같이 열에 약한 물질의 추출에 유용하며, critical point 이상의 압력 과 온도를 설정해 줌으로써 액상의 용해력과 기상의 확산계수 가 높고 점도가 낮기 때문에 빠른 추출과 상 분리가 가능하다.

최근의 초임계 유체 추출기술에는 이산화탄소가 가장 널리 이용되고 있는데, 이는 이산화탄소의 낮은 임계 온도와 압력 으로 온화한 조건에서 추출을 수행할 수 있으며, 독성, 가연성, 추출대상물질과의 반응성 및 부식성이 없고 고순도의 이산화 탄소를 쉽게 구할 수 있기 때문이다. 그리고 온도에 민감한 물질을 변성이나 분해 없이 분리할 수 있어서 식품이나 의약 품 등 인체에 직접 적용되는 제품의 생산에 매우 유용하나, 아직 추출법에 따른 유용성분의 추출과 관련된 체계적인 연구 는 없다. 또한 추출하고 남은 부산물(박)은 폐기하는 실정이므 로 이에 대한 활용방안도 고려해 보아야 한다.

따라서 본 연구에서는 천연 식물소재인 계피를 이용하여 용매추출, 초임계 추출 공정을 통한 초임계 오일과 박 추출물 의 항산화력 및 항균활성 특성을 검토하고, 각 조건별 추출물 의 cinnamaldehyde 함량을 분석하여 천연식품의 유용성분 분 리의 기초자료를 얻고자 하였다.

\section{재료 및 방법}

계피 메탄올 추출물 제조

본 실험에서 사용한 계피는 대구시 약령시장에서 건조 상태
의 것을 구입하여 분쇄한 후, 무게의 10 배량의 $(\mathrm{w} / \mathrm{v})$ 의 $80 \%$ 메탄올을 가하여 $24 \mathrm{hr}$ 정치하여 총 3 회 반복 추출하였다. 추출액은 여과지(Whatman No. 3, Whatman International Ltd., Maidstone, England)로 여과한 다음 rotary vacuum evaporator (UT-1000, EYELA, Tokyo, Japan)로 $55^{\circ} \mathrm{C}$ 에서 농 축한 후 동결 건조하여 메탄올 추출물로 사용하였다.

\section{계피 초임계 추출물(SFE Oil)의 제조}

초임계 추출에 사용할 초임계 추출 장치는 Waters AD-RC 08 (Waters CO., Milford, MA, USA)를 사용하였다. 시료를 추출 용기에 $300 \mathrm{~g}$ 을 넣어 $\mathrm{CO}_{2}$ flow rate: co-solvent의 flow rate를 $47.5 \mathrm{~g} / \mathrm{min}: 2.5 \mathrm{~g} / \mathrm{min}$ 으로 하여 total flow rate $\left(\mathrm{CO}_{2}\right.$ flow rate + co-solvent flow rate)를 $50 \mathrm{~g} / \mathrm{min}$ 의 속도로 흘려 주었고 co-solvent로는 HPLC급 ethyl alchol (JT Baker Co., Phillipsburg, NJ, USA)를 사용하였다. 추출 온도는 $35^{\circ} \mathrm{C}$, 추출 시간은 120 분으로 고정하였으며 압력을 $200,300,400 \mathrm{bar}$ 로 하여 압력이 다른 3 가지 조건에서 추출하였다. 회수된 추출물 을 $40^{\circ} \mathrm{C}$ 에서 회전진공농축기(EYELA Co., Tokyo, Japan)를 이 용하여 농축한 후 실험에 사용하였다.

\section{초임계 박 메탄올 추출물(SFM) 제조}

초임계 추출을 하고 남은 부산물인 계피 박을 무게의 10 배 $(\mathrm{w} / \mathrm{v})$ 의 메탄올 $(80 \%)$ 을 가하여 $24 \mathrm{hr}$ 정치하여 3회 반복하여 회수된 추출물을 여과하여 rotary vacuum evaporator로 $55^{\circ} \mathrm{C}$ 에서 감압 농축한 후 동결 건조하여 사용하였다.

\section{추출 수율}

추출 조건별 추출 수율은 추출 전 시료 건조물의 중량에 대비 각 추출 방법에 의해 생성된 추출 용액을 회전진공농축 기로 감압 농축하여 나온 추출물 무게에 대한 백분율로 나타 내었다.

추출수율 $(\%, \mathrm{w} / \mathrm{w})=$ 추출물건조무게 $/$ 시료건조무 게 $\times 100$

\section{$\mathrm{GC} / \mathrm{MS}$ 를 이용한 성분 분석}

계피 초임계 추출물을 $\mathrm{EtOH}$ 에 희석한 후 $0.45 \mu \mathrm{M} \mathrm{mem-}$ brane filter로 여과하여 분석 시료로 사용하였다. 실험에 사용 한 GC/MS system은 HP 190915-433 model (Paloalto, California, USA)이며 column은 HP-5MS (30 m× $0.25 \mathrm{~mm}$, $0.25 \mu \mathrm{M})$ 를 사용하였고 Detector로는 MS를 이용하였다. ESI mode에서 $70 \mathrm{eV}$ 의 에너지로 이온화하였으며 TIC의 SCAN mode에서 검출이온 질량범위 35 350으로 설정하여 각 질량 스펙트럼 중에서 가장 강도가 강한 main fragment ion을 중심 으로 라이브러리를 검색하여 물질 확인 분석을 하였다. Injector temperature는 $260^{\circ} \mathrm{C}$, detector temperature는 $280^{\circ} \mathrm{C}$ 이며 carrier gas는 helium을 사용하여 flow rate를 $1 \mathrm{ml} / \mathrm{min}$ 으로 사용하였다. Oven temperature는 최초 $50^{\circ} \mathrm{C}$ 에서 5 분 동 
안 유지한 후 $4^{\circ} \mathrm{C} / \mathrm{min}$ 속도로 $200^{\circ} \mathrm{C}$ 까지 상승시킨 후, $200^{\circ} \mathrm{C}$ 에서 $20^{\circ} \mathrm{C} / \mathrm{min}$ 속도로 $280^{\circ} \mathrm{C}$ 까지 온도를 상승시킨 후 20 분간 유지하였다. 라이브러리를 통해 검색된 main peck인 계피의 주요 성분인 cinamaldehyde는 $50,500,1,000 \mathrm{ppm}$ 의 농도로 제조한 후 정량 분석에 이용하였다.

\section{활성}

a-a-diphenyl- $\beta$-picrylhydrazyl (DPPH) radical 소거

시료의 free radical 소거 활성은 stable radical인 a-a

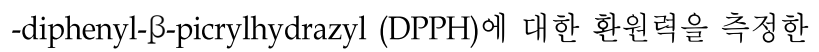
것으로 $99 \%$ 메탄올에 각 시료를 녹여 농도별로 희석한 희석액 $160 \mu \mathrm{l}$ 와 메탄올에 녹인 $0.15 \mathrm{mM} \mathrm{DPPH}$ 용액 $40 \mu \mathrm{l}$ 를 가하여 실온에 30분 방치한 후 $517 \mathrm{~nm}$ 에서 흡광도를 측정하였다. 각 시료 추출물의 유리라디칼 소거활성은 시료를 첨가하지 않은 대조구의 흡광도를 $1 / 2$ 로 환원시키는데 필요한 시료의 농도 인 $\mathrm{RC}_{50}$ 값으로 나타내었다. 이때 활성비교를 위하여 $\mathrm{BHA}$ 를 사용하였다.

\section{ABTS radical 소거 활성}

$7 \mathrm{mM}$ 2,2'-azino-bis (3-ethylbenzthiazoline-6-sulfonic acid) (ABTS, Sigma Chemical Co., St. Louis, MO, USA)와 $2.45 \mathrm{mM}$ potassium persulfate를 최종 농도로 혼합하여 실온 인 암소에서 24시간 동안 방치하여 ABTS+·을 형성시킨 후 96 well에 $734 \mathrm{~nm}$ 에서 흡광도 값이 $0.70( \pm 0.02)$ 이 되게 phosphate buffer saline (PBS, pH 4)로 희석하였다. 희석된 용액 $180 \mu 1$ 에 sample $20 \mu 1$ 를 가하여 정확히 1분 동안 방치한 후 흡광도를 측정하였다. 각 시료 추출물과 단일 물질의 유리 라 디칼 소거 활성은 시료를 첨가하지 않은 대조구의 흡광도를 $1 / 2$ 로 환원시키는데 필요한 시료의 농도인 $\mathrm{RC}_{50}$ 값으로 나타 내었다.

\section{사용 균주 및 배지}

본 실험에서 사용한 Escherichia coli $\mathrm{O} 157: \mathrm{H} 7$ 의 표준균주인 ATCC 4388, Bacillus cereus의 표준균주인 ATCC 12573은 미 국균주보존센터로부터, Staphylococcus aureus의 표준균주인 KCTC 1621, Listeria monocytogene의 표준균주인 KCTC 3710은 한국생명공학연구원 생물자원센터로부터, Streptococcus $m u-$ tans 의 표준균주인 KCCM 40105, Salmonella typhimurium의 표준균주인 KCCM 11862, Pseudomonas aeruginosa의 표준균주 인 KCCM 1132, Vibrio parahaemolyticus의 표준균주인 KCCM 11965 을 한국미생물보전센터로부터 분양 받아 각각의 균들을 tryptic soy broth (TSB, Difco, Detroit, USA)에 1백금이 접종 하여 $37^{\circ} \mathrm{C}$ 에서 24 시간 shaking하여 3회 계대 배양 후 성장 최적조건에서 배양 시켰다. 또한, 생균수 측정을 위한 배지는 tryptic soy agar (TSA, Difco)를, 세균을 희석하기 위한 희석수 로는 멸균 증류수를 사용하였다.

\section{항균활성 측정}

추출물의 항균력 검색은 disc diffusion method [16]법을 실시하였다. 균주를 $100 \mathrm{ml} \mathrm{TSB}$ 에 접종하고 $37^{\circ} \mathrm{C}$ 에서 shaking 하면서 24시간 배양하여 활성화시키고 3 일 계대 배양 후 spectrophotometer (UNIKON922, Kontron, Milan, Italy)를 이용 하여 $560 \mathrm{~nm}$ 에서 O. D. 값이 0.2 가 되게 하여 균수를 $1 \times 10^{7}$ $\mathrm{cfu} / \mathrm{ml}$ 로 사용하였다. 고체배지에 멸균된 glass spreader로 균 을 고르게 spread 한 후, $8 \mathrm{~mm}$ paper disc (diamerter $8 \mathrm{~mm}$, Adantec co., Tokyo, Japan)를 올려놓은 다음 추출물을 최종농 도가 $0.5,2.5,5 \mathrm{mg} / \mathrm{disc}$ 가 되도록 $\mathrm{DMSO}$ 에 용해시키고 50 $\mu 1$ 를 주입하여 완전히 흡수시킨 후 $37^{\circ} \mathrm{C}$ incubator에서 24 시간 배양시켜 paper disc 주위의 inhibition zone $(\mathrm{mm})$ 의 직경을 측정하였다.

\section{결과 및 고찰}

계피 메탄올 추출물과 초임계 추출물의 수율

계피 메탄올 추출물과 초임계 오일과 박 메탄올 추출물(SFE oil: Supercritical Fluid Extraction oil, SFM: Methanol extract of SFE Marc)의 수율은 Table 1에 나타낸 것과 같이 계피의 메탄올 추출물은 $19.93 \%$ 의 수율을 보였다. 계피의 초임계 추 출을 위한 최적의 조건을 검토하기 위하여 $35^{\circ} \mathrm{C}$ 에서 200,300 , $400 \mathrm{bar}$ 의 압력 조건에서 초임계 추출을 실시한 결과, 초임계 오일과 박 메탄올 추출물의 수율은 용매 추출물에 비해 다소 낮은 추출 수율을 보였으나, SFE oil과 SFM에서 압력이 높아 질수록 수율이 증가하는 경향을 보였다. 생강 초임계 오일에 서 온도에 관계없이 압력이 높아질수록 수율이 증가하였고 [15], 개다래의 경우 초임계 추출물에서 온도, 압력, 시간에 비 례적으로 수율이 증가하였다고 보고했다[26]. 또한 초임계 유 체 추출법에서는 보조용매의 사용에 따라 수율이 달라지는데, 우슬의 $\beta$-ecdysone 추출의 최적조건은 $80^{\circ} \mathrm{C}, 300 \mathrm{~atm}, 20 \%$ methanol 조건에서 가장 높은 수율을 보였으며[23], 당근의

Table 1. The extraction yield of $\mathrm{MeOH}$ extracts and SFE, SFM from Cinnamomun verum according to different extraction conditions

\begin{tabular}{ccc}
\hline \multicolumn{2}{c}{ Condition } & Extraction yield (\%) \\
\hline \multirow{3}{*}{$\mathrm{SFE}^{\mathrm{b}}$} & $80 \% \mathrm{MeOH}^{\mathrm{a}}$ & 19.93 \\
& $200 \mathrm{bar}$ & 4.86 \\
& $300 \mathrm{bar}$ & 4.73 \\
$\mathrm{SFM}^{\mathrm{c}}$ & $400 \mathrm{bar}$ & 7.56 \\
& $200 \mathrm{bar}$ & 7.83 \\
& $300 \mathrm{bar}$ & 8.64 \\
& $400 \mathrm{bar}$ & 10 \\
\hline
\end{tabular}

${ }^{\mathrm{a}} 80 \% \mathrm{MeoH}$ : Methanol Extract of Cinnamomum verum ${ }^{b}$ SFC: Supercritical Fluid Extracts

'SFM: Methanol extracts of SFE marc (removed oil) 
carotenoid 추출시에는 $50^{\circ} \mathrm{C}, 300 \mathrm{~atm}, 10 \%$ ethanol 조건에서 가장 많이 추출되었다[22]. 따라서 초임계 유체 추출의 수율에 가장 많은 영향을 미치는 것은 압력이라 생각되고, 추출되는 천연물 성분의 화학적 성질에 따라서 온도, 보조용매 등에 의 해 수율이 달라진다.

\section{$\mathrm{GC} / \mathrm{MS}$ 를 이용한 cinnamaldehyde 함량 분석}

각 조건별 계피 추출물을 $\mathrm{GC} / \mathrm{MS}$ 를 이용하여 정유성분과 화학구조를 규명한 결과 (E)-cinnamaldehyde의 peak를 관찰하 였고 화학구조를 규명한 결과는 Fig. 1과 같다. Cinnamaldehyde 함량을 구한 결과는 Table 2에 나타내었다. 그 결과 $80 \%$ 메탄 올 추출물에 비해 SFE oil에서 cinnamaldehyde 함량이 약 30 60배 이상 많이 함유되어 있었고, 특히 $300 \mathrm{bar}$ 에서 cinnamaldehyde 함량이 가장 높음을 알 수 있었다. SFM에서는 $80 \%$ 메탄올 추출물 보다 cinnamaldehyde 함량이 적었고 압력 이 높을수록 함량이 줄어드는 것을 확인하였다. 계피의 volatile oil과 oleoresin의 GC/MS 분석 결과 cinnamaldehyde가 검출된 성분의 $97 \%$ 를 차지하고, oleoresin의 경우는 cinnamaldehyde가 검출된 성분의 $50 \%$ 를 구성하고 있다고 보고되 어있다[8]. Cinnamaldehyde의 물리적 특성은 boiling point는 $246^{\circ} \mathrm{C}$, water solubility는 $1,420 \mathrm{mg} / \mathrm{ml}\left(25^{\circ} \mathrm{C}\right)$ 이다[6]. 따라서 기존의 oil을 추출하는 soxhlet 추출법에 비해 초임계 추출법 을 이용했을 때 더 많은 cinnamaldehyde를 얻을 수 있었다.

\section{DPPH free radical 소거활성}

$\mathrm{DPPH}$ 는 분자 내 free radical을 가지고 있는 수용성 물질로

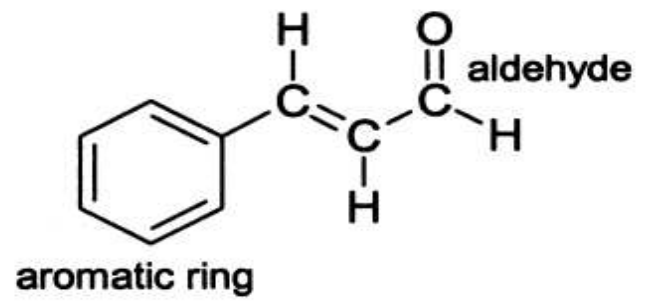

Fig. 1. Chemical structure of cinnamaldehyde.

Table 2. Cinnamaldehyde contents in $\mathrm{MeOH}$ extracts and SFE, SFM from Cinnamomun verum according to different extraction conditions

\begin{tabular}{ccc}
\hline \multicolumn{2}{c}{ Condition } & Cinnamaldehyde content $(\mathrm{mg} / 100 \mathrm{~g})$ \\
\hline \multicolumn{2}{c}{$80 \% \mathrm{MeOH}$} & 595.52 \\
\hline \multirow{3}{*}{$\mathrm{SFE}$} & $200 \mathrm{bar}$ & 17107.38 \\
& $300 \mathrm{bar}$ & 35220.56 \\
& $400 \mathrm{bar}$ & 28029.12 \\
\hline \multirow{3}{*}{$\mathrm{SFM}$} & $200 \mathrm{bar}$ & 417.33 \\
& $300 \mathrm{bar}$ & 266.95 \\
& $400 \mathrm{bar}$ & 163.87 \\
\hline
\end{tabular}

ascorbic acid, tocopherol, polyhydroxy 방향족 화합물 등에 의해 환원되어 짙은 자색이 탈색되는데, 이 때 분자의 움직임 은 hydroxyl radical과 유사하여 다양한 천연 소재로부터 항산 화 물질을 검색하는데 많이 이용되고 있다[4,10]. ROS (reactive oxygen species)는 체내 방어기전에 의해 대부분 제 거되지만 제거되지 못할 경우 생체분자들과 신속하게 반응하 여 단백질의 변성이나 생체막의 지질 과산화, DNA 손상 등을 일으키며, 세포 내로 확산되거나 혈류를 통해 이동된 지질 과 산화물은 새로운 radical 반응을 촉진시켜 각종 질환의 원인으 로 작용 한다[7]. 계피 methanol 추출물 및 초임계 추출물, 초 임계 추출물 박의 DPPH free radical 소거활성을 합성 항산화 제인 BHA와 비교한 결과를 Table 3에 나타내었다. 계

Table 3. Scavenging effects of $\mathrm{MeOH}$ extracts and SFE, SFM from Cinnamomun verum and cinnamaldehyde, butylated hydroxyanisole (BHA) on a,a-diphenyl- $\beta$ -picrylhydrazyl radical (DPPH)

\begin{tabular}{|c|c|c|c|c|}
\hline \multicolumn{2}{|c|}{ Condition } & Concentration $^{\mathrm{a}}$ & $\begin{array}{l}\text { Scavenging } \\
\text { effect }(\%)\end{array}$ & $\mathrm{RC}_{50}{ }^{\mathrm{b}}$ \\
\hline \multirow{3}{*}{\multicolumn{2}{|c|}{$80 \% \mathrm{MeOH}$}} & 1 & - & \\
\hline & & 10 & $26.98 \pm 3.65$ & $40.81 \pm 3.45$ \\
\hline & & 100 & $93.98 \pm 0.64$ & \\
\hline \multirow{3}{*}{\multicolumn{2}{|c|}{ Cinnamaldehyde }} & 1 & - & - \\
\hline & & 10 & - & - \\
\hline & & 100 & - & - \\
\hline \multirow{9}{*}{ SFE } & \multirow{3}{*}{200 bar } & 1 & - & - \\
\hline & & 10 & - & - \\
\hline & & 100 & - & - \\
\hline & \multirow{3}{*}{300 bar } & 1 & - & - \\
\hline & & 10 & - & - \\
\hline & & 100 & - & - \\
\hline & \multirow{3}{*}{400 bar } & 1 & - & - \\
\hline & & 10 & - & - \\
\hline & & 100 & - & - \\
\hline \multirow{12}{*}{ SFM } & \multirow{3}{*}{200 bar } & 1 & - & \multirow{3}{*}{$36.85 \pm 1.99$} \\
\hline & & 10 & $68.13 \pm 5.21$ & \\
\hline & & 100 & $89.45 \pm 1.53$ & \\
\hline & \multirow{3}{*}{300 bar } & 1 & $1.32 \pm 1.50$ & \multirow{3}{*}{$35.65 \pm 4.63$} \\
\hline & & 10 & $62.21 \pm 9.40$ & \\
\hline & & 100 & $88.72 \pm 0.20$ & \\
\hline & \multirow{3}{*}{400 bar } & 1 & $14.44 \pm 4.06$ & \multirow{3}{*}{$35.99 \pm 3.12$} \\
\hline & & 10 & $50.77 \pm 2.88$ & \\
\hline & & 100 & $86.60 \pm 3.21$ & \\
\hline & \multirow{3}{*}{ BHA } & 1 & $5.81 \pm 7.44$ & \multirow{3}{*}{$15.11 \pm 2.03$} \\
\hline & & 10 & $38.90 \pm 7.14$ & \\
\hline & & 20 & $62.32 \pm 4.94$ & \\
\hline
\end{tabular}

${ }^{a}$ The concentration unit of $\mathrm{MeOH}, \mathrm{SFC}$, SFM, cinnamaldehyde were $\mu \mathrm{g} / \mathrm{ml}$ and BHA was $\mu \mathrm{M}$.

${ }^{b}$ Concentration required for $50 \%$ reduction of DPPH radical at $30 \mathrm{~min}$ after starting the reation $(\mathrm{\mu g} / \mathrm{ml}$ or $\mu \mathrm{M})$.

${ }^{c}$ Each value is mean \pm S.D $(\geq 3)$. 
Table 4. Scavenging effects of $\mathrm{MeOH}$ extracts and SFE, SFM from Cinnamomun verum and cinnamaldehyde, trolox on 2,2'-azino-bis (3-ethylbenzthiazoline-6-sulfonic acid) radical (ABTS+)

\begin{tabular}{|c|c|c|c|c|}
\hline \multicolumn{2}{|c|}{ Condition } & Concentration $^{\mathrm{a}}$ & $\begin{array}{l}\text { Scavenging } \\
\text { effect }(\%)\end{array}$ & $\mathrm{RC}_{50}^{\mathrm{b}}$ \\
\hline \multirow{3}{*}{\multicolumn{2}{|c|}{$80 \% \mathrm{MeOH}$}} & 1 & $1.70 \pm 1.37$ & \multirow{3}{*}{$41.30 \pm 2.68$} \\
\hline & & 10 & $45.11 \pm 5.49$ & \\
\hline & & 100 & $93.12 \pm 0.23$ & \\
\hline \multirow{3}{*}{\multicolumn{2}{|c|}{ Cinnamaldehyde }} & 1 & - & - \\
\hline & & 10 & - & - \\
\hline & & 100 & - & - \\
\hline \multirow{3}{*}{\multicolumn{2}{|c|}{200 bar }} & 1 & - & - \\
\hline & & 10 & - & - \\
\hline & & 100 & - & - \\
\hline \multirow{6}{*}{ SFE } & \multirow{3}{*}{300 bar } & 1 & - & - \\
\hline & & 10 & - & - \\
\hline & & 100 & - & - \\
\hline & \multirow{3}{*}{400 bar } & 1 & - & - \\
\hline & & 10 & - & - \\
\hline & & 100 & - & - \\
\hline \multirow{9}{*}{ SFM } & \multirow{3}{*}{200 bar } & 1 & $1.51 \pm 0.76$ & \multirow{3}{*}{$40.95 \pm 3.07$} \\
\hline & & 10 & $46.02 \pm 6.48$ & \\
\hline & & 100 & $93.21 \pm 0.09$ & \\
\hline & \multirow{3}{*}{300 bar } & 1 & $3.96 \pm 0.45$ & \multirow{3}{*}{$32.04 \pm 1.86$} \\
\hline & & 10 & $63.66 \pm 4.03$ & \\
\hline & & 100 & $92.10 \pm 0.08$ & \\
\hline & \multirow{3}{*}{400 bar } & 1 & $0.88 \pm 0.47$ & \multirow{3}{*}{$40.16 \pm 1.26$} \\
\hline & & 10 & $49.81 \pm 3.40$ & \\
\hline & & 100 & $92.24 \pm 0.77$ & \\
\hline \multirow{4}{*}{\multicolumn{2}{|c|}{ Trolox }} & 10 & $15.33 \pm 0.56$ & \multirow{4}{*}{$30.38 \pm 1.21$} \\
\hline & & 20 & $28.36 \pm 7.03$ & \\
\hline & & 30 & $60.45 \pm 1.31$ & \\
\hline & & 60 & $93.26 \pm 0.18$ & \\
\hline
\end{tabular}

${ }^{a}$ The concentration unit of $\mathrm{MeOH}, \mathrm{SFC}, \mathrm{SFM}$, (E)-cinnamaldehyde were $\mu \mathrm{g} / \mathrm{ml}$ and trolox was $\mu \mathrm{M}$.

${ }^{b}$ Concentration required for $50 \%$ reduction of ABTS radical at $1 \mathrm{~min}$ after starting the reation $(\mu \mathrm{g} / \mathrm{ml}$ or $\mu \mathrm{M})$.

${ }^{c}$ Each value is mean \pm S.D $(\geq 3)$.

피 SFE oil을 제외한 모든 조건에서 $\mathrm{DPPH}$ 소거활성이 높게 나타났으며, 특히 $80 \%$ methanol 추출물 $100 \mu \mathrm{g} / \mathrm{ml}$ 에서 $93.98 \%$ 의 DPPH 소거활성이 나타났으며, SFM 중 $200 \mathrm{bar} 100$ $\mu \mathrm{g} / \mathrm{ml}$ 에서 $89.45 \%$ 로 $\mathrm{SFM}$ 중 가장 높은 소거활성을 가지는 것으로 나타났다. Cinnamaldehyde와 SFE oil은 DPPH 활성 이 나타나지 않았다. 계피의 경우 정유성분에 대한 연구가 대 부분이며, 정유성분의 경우도 cinnamaldehyde의 기능성 항돌 연변이, 항암 등에 대한 연구가 많다[9,19]. 반면 계피의 항산화 력이나 항산화물질에 대한 연구는 미비하고, 정유 추출 후 남 은 부산물에 대한 효능평가는 거의 이루어지지 않았기 때문에 본 연구에서 계피 박 추출물의 $\mathrm{DPPH}$ 라디칼 저해는 계피를 항산화 소재로 사용할 수 있는 새로운 연구이다.

\section{ABTS free radical 소거활성}

ABTS radical을 이용한 항산화능 측정은 potassium persulfate와 반응하여 암소에 방치하면 ABTS radical이 생성되는데 추출물의 항산화력에 의해 ABTS radical이 소거되어 radical 특유의 색인 청록색이 탈색되는 원리를 이용한다. ABTS radi$\mathrm{cal}$ 탈색 반응은 1 분 안에 종료 되므로 단시간에 측정할 수 있고, 극성과 비극성 물질 모두에 적용 가능하다[24].

본 실험에서는 $80 \%$ methanol 추출물, SFE oil, SFM, cinnamaldehyde 및 trolox의 ABTS+・의 소거활성을 측정하여 Table 4에 나타내었다. 계피 methanol 추출물은 $100 \mu \mathrm{g} / \mathrm{ml}$ 의 농도에서 $93.12 \%$ 의 높은 $\mathrm{ABTS}+$ - 소거 활성을 보였고, $\mathrm{SFM}$ 중 $200 \mathrm{bar} 100 \mu \mathrm{g} / \mathrm{ml}$ 의 농도에서 $93.21 \%$ 의 높은 ABTS+ • 소거 활성을 보였다. 계피 methanol 추출물과 SFM에서 높은 활성을 나타낸 반면에 cinnamaldehyde, SFE oil 은 ABTS+ 소거활성이 없었다. 이러한 항산화 결과는 cinnamaldehyde와 cinnamaldehyde 함량이 많은 SFC oil 보다 $80 \%$ methanol추 출물과 SFM에 polyphenol과 같은 항산화 성분이 많이 포함되 어 있기 때문이라 생각된다. 이전의 보고에 의하면 용매에 따 라 70\% methanol, $70 \%$ ethanol에서 항산화력과 polyphenol 의 함량이 가장 많았고 hexane, chloroform 등의 비극성 용매 추출물에서는 항산화력과 polyphenol함량이 적었다[12].

\section{계피 조건별 추출물 및 단일성분의 균 생육억제 효과}

계피 추출물을 이용하여 $\mathrm{Gram}(+)$ 균과 $\mathrm{Gram}(-)$ 균에 대한 항균효과를 검색한 결과는 Table 5에서 보는 것과 같이 SFE oil, cinnamaldehyde에서 모든 식중독 균에 대해 inhibition zone을 나타냈다. 그러나, $80 \%$ methanol 추출물과 SFM에서 는 항균활성이 없었다. Gram(+)균에서는 B. cereus, L. monocytogenes균에 대해 SFE oil 200 bar, 300 bar에서 높은 inhibition zone을 보였고, 나머지 Gran(+)균에서는 SFE oil의 모든 압력조건에서 높은 inhibition zone을 보였다. 특히 Gram(-)균 중 E. coli 에서는 cinnamaldehyde $2.5 \mathrm{mg} / \mathrm{ml}$ 의 농도에서 가장 높은 inhibition zone을 나타냈으며, SFE oil에 서는 압력 조건에 관계없이 200, 300, $400 \mathrm{bar} 2.5 \mathrm{mg} / \mathrm{ml}$ 이상 의 농도에서 높은 항균력을 보였다. 이에 반해 cinnamaldehyde성분이 적게 함유된 $80 \%$ methanol 추출물, SFM에서는 항균력 없었다. Cinnaaldehyde가 식중독균에 대해 항균력을 나타냈다고 보고되었으나[8,11], 본 논문에서는 다른 camphene, cineole, eugenol[8] 등의 성분들의 상호간의 상승 작용 에 의해 SFE oil이 cinnamaldehyde보다 높은 항균력을 나타내 는 것이라 생각된다.

\section{감사의 글}

이 논문은 2011학년도 계명대학교 대학원 학술연구 논문 장학금과 교육과학기술부와 한국연구재단의 지역현신인력양 
Table 5. Antimicrobial activites of $\mathrm{MeOH}$ extracts and SFE, SFM from Cinnamomun verum and cinnamaldehyde

\begin{tabular}{|c|c|c|c|c|c|c|c|c|c|c|}
\hline \multirow{2}{*}{\multicolumn{2}{|c|}{ Condition }} & \multirow{2}{*}{$\begin{array}{c}\text { Concentration } \\
\text { (mg/disc) }\end{array}$} & \multicolumn{4}{|c|}{$\operatorname{Gram}(+)$} & \multicolumn{4}{|c|}{ Gram(-) } \\
\hline & & & $\mathrm{BA}^{\mathrm{a}}$ & SA & SM & LM & $\mathrm{EC}$ & ST & PA & VP \\
\hline \multirow{2}{*}{$80 \%$} & \multirow{2}{*}{$\mathrm{MeOH}$} & $2.5 \mathrm{mg}$ & - & - & - & - & - & - & - & - \\
\hline & & $5 \mathrm{mg}$ & - & - & - & - & - & - & - & - \\
\hline \multirow{2}{*}{\multicolumn{2}{|c|}{ Cinnamaldehyde }} & $2.5 \mathrm{mg}$ & $3.07 \pm 0.05$ & $1.77 \pm 0.11$ & $1.43 \pm 0.05$ & $1.43 \pm 0.05$ & $3.30 \pm 0.26$ & $2.23 \pm 0.51$ & $1.06 \pm 0.05$ & $1.57 \pm 0.05$ \\
\hline & & $5.0 \mathrm{mg}$ & $1.70 \pm 0.17$ & $4.03 \pm 0.47$ & $2.37 \pm 0.05$ & $2.47 \pm 0.05$ & $2.23 \pm 0.51$ & $3.3 \pm 0.26$ & $1.87 \pm 1.1$ & $2.00 \pm 0.20$ \\
\hline \multirow{6}{*}{ SFE } & \multirow{2}{*}{200 bar } & $2.5 \mathrm{mg}$ & $3.43 \pm 0.057^{b}$ & $2.7 \pm 0.26$ & $2.00 \pm 0.00$ & $1.80 \pm 0.00$ & $2.60 \pm 0.10$ & $4.40 \pm 0.17$ & $1.20 \pm 0.10$ & $1.47 \pm 0.11$ \\
\hline & & $5.0 \mathrm{mg}$ & $3.27 \pm 0.11$ & $3.97 \pm 0.05$ & $1.57 \pm 0.05$ & $3.00 \pm 0.17$ & $1.47 \pm 0.05$ & $4.70 \pm 0.60$ & $1.73 \pm 0.23$ & $2.06 \pm 0.05$ \\
\hline & \multirow{2}{*}{300 bar } & $2.5 \mathrm{mg}$ & $3.27 \pm 0.38$ & $2.47 \pm 0.26$ & $1.57 \pm 0.05$ & $1.60 \pm 0.00$ & $2.20 \pm 0.10$ & $4.07 \pm 0.20$ & $1.13 \pm 0.05$ & $1.53 \pm 0.11$ \\
\hline & & $5.0 \mathrm{mg}$ & $3.27 \pm 0.11$ & $4.10 \pm 0.1$ & $1.63 \pm 0.11$ & $3.10 \pm 0.17$ & $1.17 \pm 0.05$ & $4.93 \pm 0.28$ & $1.63 \pm 0.05$ & $2.03 \pm 0.05$ \\
\hline & \multirow{2}{*}{400 bar } & $2.5 \mathrm{mg}$ & $3.67 \pm 0.28$ & $3.47 \pm 0.11$ & $1.53 \pm 0.05$ & $1.53 \pm 0.05$ & $2.00 \pm 0.10$ & $4.30 \pm 0.26$ & $1.00 \pm 0.00$ & $1.47 \pm 0.05$ \\
\hline & & $5.0 \mathrm{mg}$ & $2.83 \pm 0.15$ & $4.13 \pm 0.11$ & $2.00 \pm 0.00$ & $2.63 \pm 0.05$ & $1.47 \pm 0.057$ & $4.37 \pm 0.32$ & $1.20 \pm 0.10$ & $2.10 \pm 0.10$ \\
\hline \multirow{6}{*}{ SFM } & \multirow{2}{*}{200 bar } & $2.5 \mathrm{mg}$ & $\mathrm{c}$ & - & - & - & - & - & - & - \\
\hline & & $5.0 \mathrm{mg}$ & - & - & - & - & - & - & - & - \\
\hline & \multirow{2}{*}{300 bar } & $2.5 \mathrm{mg}$ & - & - & - & - & - & - & - & - \\
\hline & & $5.0 \mathrm{mg}$ & - & - & - & - & - & - & - & - \\
\hline & \multirow{2}{*}{400 bar } & $2.5 \mathrm{mg}$ & - & - & - & - & - & - & - & - \\
\hline & & $5.0 \mathrm{mg}$ & - & - & - & - & - & - & - & - \\
\hline
\end{tabular}

${ }^{a}$ BC: Bacillus cereus ; SA: Staphylococcus aureus, SM: Streptococcus mutans, LM: Listeria monocytogenes,

EC: Escherichia coli; ST: Sallmonella typhimurium, PA: Pseudomoans aeruginosa, VP: Vibrio parahaemolyticus

${ }^{\mathrm{b}}$ Paper disc $(5 \mathrm{~mm})$ was included.

${ }^{\mathrm{c}} \mathrm{NO}$ inhibition

성사업으로 수행되었음에 감사드립니다.

\section{References}

1. Block, G. and L. Langseth. 1994. Antioxidants vitamins and disease prevention. Food Technol. 48, 80-84.

2. Cherry, J. P. 1999. Improving the safety of fresh produce with antimicrobials. Food Technol. Chicago 53, 53-59.

3. Cho, M. H., E. K. Bae, S. D. Ha, and J. Y. Park. 2005. Application of natural antimicrobial to food industry. Food Sci. Indus. 38, 36-45.

4. Cho, S. Y., Y. B. Han, and K. H. Shin. 2001. Screening for antioxidants activity of edible plants. J. Korean Soc. Food Sci. Nutr. 30, 133-137

5. Doldberg, I. 1994. Functional Foods. pp. 3-550, Chapman \& Hall Press. New York.

6. Donald, G. and M. D. Barceloux. 2009. Cinnamon (Cinnamomum Species). pp. 39-43, Toxicology of Natural Substance.

7. Fukuzawa, K. and Y. Takaishi. 1990. Antioxidant. J. Act. Oxyg. Free Rad 1, 55-70.

8. Gurdi, S., M. Sumitra, M. P. Delampasona, and A. N. Cesar. 2007. A comparison of chemical, antioxidant and antimicrobial studies of cinnamon leaf and bark volatile oils, oleoresin and their constituent. Food Chem Toxicol. 45, 1650-1661

9. Ka, H., H. J. Park., H. J. Jung., J. W. Choi., K. S. Cho, J. H. Ha, and K. T. Lee. 2003. Cinnamaldehyde induces apoptosis by ROS-mediated mitochondrial permeability tran- sition in human promyelocytic leukemia HL-60 cells. Cacncer Lett. 196, 143-152.

10. Kang, M. H., C. S. Choi, Z. S. Kim, H. K. Chung, K. S. Min, C. G. Park, and H. W. Park. 2002. Antioxidative Activities of Ethanol Extract Prepared from Leaves, Seed, Branch and Aerial Part of Crotalaris sessiflora L. Korean J. Food Sci. Alcohol 34, 1098-1102.

11. Kim, N. M., H. S. Sung, and W. J. Woo. 1993. Effect of solvents and someextraction codition on antioxidant activity in Cinnamon extracts. Korean. J. Food Sci. Technol. 25, 204-209.

12. Kim, S. H., M. J. Chung, H. D. Jang, and S. S. Ham. 2010. Antioxidative activities of the Codonopsis lanceolata extract in vitro and in viva J. Korean Soc. Food Sci. Nutr. 39, 193-202.

13. Kim, S. K., H. J. Lee, and M. K. Kim. 2001. Effect of water and ethanol extracts of persimmon leaf and green tea different condition on lipid metabolism and antioxidative capacity in 12-month-old rats. J. Korean Nutr. 34, 499-512.

14. Kim, Y. S., I. S. Park, and S. D. Ha. 2009. Application sanitizer for the control of microorganism in food. Food Sci. Indus. 42, 26-51.

15. Lee, E. J., S. A. Yang, H. D. Choi, H. G. Im, K. Whang, and I. S. Lee. 2011. Comparison of gingerols in various fraction and the antioxidative effects of supercritical fluid extracts from Ginger. J. Korean Soc. Food Sci. Nutr. 32, 723-727.

16. Lee, H, and Y. O. You. 2004. Inhibitory effect of Caeaslpinia sappan on caries inducing properties of Streptococcus mutans and isolation of antibacteria component, brazilian. Wonkwang Univ. Dent. 13, 63-68. 
17. Libby, P. P., M. Ridker, and A. Maseri. 2002. Inflammation and atherosclerosis. Circulation 105, 1135-1143.

18. Mchugh, M. A. and V. J. Krukonis. 1986. Supercritical fluid extraction: Principle and practice. pp. 608, Butterworths, Stoneham, MA, USA.

19. Ohta, T., K. Watanabe, M. Moriya, and Y. Shirasu. 1983. Antimutagenic effects of cinnamaldehyde on chemical mutagenesis in Escherichia coli. Mutat. Res.-Fund Mol. M. 107, 219-227.

20. Ross, R. 1999. An inflammatory disease. New Engl. J. MED. 340, 115-126.

21. Sadaki, O. 1996. The development of functional foods and materials. Bioindustry 13, 44-50.

22. Scott, L. T., J. W. King, J. L. Richard, and J. I. Greer. 1993. Analytical-scale supercritical fluid extraction of aflatoxin B1 from field-inoculate corn. J. Agric. Food Chem 41, 910-913.

23. Shim, J. H., M. R. Kim, and M. S. Kim. 2001. Study on the solvent extraction and surpercritical fluid extration method of $\beta$-ecdysone in achyranthis radix. J. Korean Soc. Agric. Chem Biotechnol. 44, 197-201.

24. Van den Berg, R., G. R., Haenen, H., Van den Berg, A. and
Bast. 1999. Applicability of an improved Trolox equivalent antioxidant capacity (TEAC) assay for evaluation of antioxi-dant capacity measurements of mixtures. Food Chem 66, 511-517.

25. Yu, B. P. 1996. Aging and oxidative stress: Modulation by dietary restriction. Free Radic. Biol. Med 21, 651-668.

26. Yu, M. H., I. G. Chae, J. H. Choi, H. G. Im, S. A. Yang, J. H. Lee, and I. S. Lee. 2010. Effects of supercritical fluid Marc extracts from actinidia polygama Max. on inflammation and atherosclerosis. J. Korean Soc. Food Sci. Nutr. 42, 475-480.

27. Yuan, A. X., L. Qin, and D. G. Jiang. 1981. Studies on chemical constituents of Cinnamum cassia. Chinese Pharmaceutical Bulletin 16, 631.

28. Yuan, A. X., L. Tan, and D. G. Jiang. 1982. Studies on chemical constituents of Cinnamum cassia. I. Bulletin of Chinese Materia Medica. 7, 26-28.

29. Yuan, A. X., L. Tan, S. X. Wei, S. H. Kang, and D. G. Jiang. 1984. Chemical constituents og Giuzi (Cinnamomum cassia), a traditional Chinese medicine. Bulletin of chinese Materia Medica 9, 127-128.

\section{초록 : 계피 초임계 추출물 및 박 추출물의 항균·항산화 활성 비교}

박성진 $^{1+} \cdot$ 유미희 ${ }^{1+} \cdot$ 김지은 ${ }^{1} \cdot$ 이삼빈 ${ }^{1,2} \cdot$ 이인선 ${ }^{1} *$

( ${ }^{1}$ 계명대학교 식품가공학 전공, ${ }^{2}$ 계명대학교 전통미생물자원개발 및 산업화연구(TMR)센터)

본 연구에서는 계피 초임계 추출물(SFE oil)과 박 추출물(SFM), $80 \%$ methanol 추출물, cinnamaldehye의 항균, 항산화력을 비교하였다. 그 결과 추출조건에 따라 뚜렷한 효과의 차이를 나타내었으며, $80 \%$ methanol 추출물과 $\mathrm{SFM}$ 이 강력한 항산화능 보였다. 반면에 항균효과에서는 cinnamaldehyde와 SFE oil에서 식중독균에 대한 항균효 과가 뛰어났으며, 초임계를 이용한 추출에서 cinnamaldehyde 이외에 다른 camphene, cineole, eugenol 등의 정 유성분들이 항균효과에 영향을 미친 것으로 생각된다. 이러한 결과로부터, 초임계 추출법이 항균물질 및 정유성 분 추출에 매우 용이할 뿐만 아니라, 초임계 추출 후 폐기되고 있는 박에서도 유용성분이 함유되어 있음을 확인 하였으므로 계피의 초임계 추출물 및 박 추출물 모두 기능성 천연소재로의 활용이 가능할 것으로 기대된다. 